\title{
ARTYKUŁY
}

Klio. Czasopismo poświęcone dziejom Polski i powszechnym

PL ISSN 1643-8191, t. 50 (3)/2019, s. 109-136

(c) (1) $\Theta$

http://dx.doi.org/10.12775/KLIO.2019.039

KRZYSZTOF KUBIAK"

\section{Mozambickie zmagania Portugalczyków w czasie I wojny światowej}

\section{Mozambique struggles of the Portuguese during World War I}

Streszczenie: W literaturze historycznej przebieg Wielkiej Wojny w Afryce zdominowany jest przez zmagania toczone między siłami niemieckimi, nader udatnie dowodzonymi przez początkowo podpułkownika, a ostatecznie generała majora Paula von LettowVorbecka a oddziałami brytyjskimi. Jest to o tyle zasadne, że na wschodzie Czarnego Kontynentu Niemcy utrzymali się, przysparzając aliantom poważnych problemów, aż do zawieszenia broni na zachodzie Europu w listopadzie 1918 roku. W narracji tej stosunkowo rzadko znajduje się miejsce na szerszy opis walk między Niemcami a Portugalczykami w Mozambiku. Luzytański wysiłek militarny opisywany był głównie, a przy tym niechętnie, przez Brytyjczyków i Niemców ${ }^{1}$. Można nawet odnieść wrażenie, że Albion, depre-

* Uniwersytet Jana Kochanowskiego w Kielcach, ul. Żeromskiego 5, 25-369 Kielce, kkubiak@ujk.edu.pl, ORCID: 0000-0002-9623-923X.

1 Na uwagę zasługują przede wszystkim prace: P. von Lettow-Vorbeck, Heia Safari! Deutschlands Kampfin Ostafrika, Leipzig 1920; idem, Mein Leben, Biberach an der Riss 1957; U. Schulte-Varendorff, Kolonialheld für Kaiser und Führer. General Lettow-Vorbeck Mythos und Wirklichkeit, Berlin 2006; W. Stephenson, Der Löwe von Afrika. Der 
cjonując iberyjskiego sojusznika, starał się zrzucić na niego znaczną część odpowiedzialności za długi ciąg odniesionych w południowo-wschodniej Afryce niepowodzeń. Intencją autora niniejszego tekstu jest ukazanie działań portugalskich w sposób obiektywny, nieobarczony brytyjską ani niemiecką narracją imperialną. Służy temu, przede wszystkim, sięgnięcie do materiałów portugalskich. Jest to - według wiedzy autora - prawdopodobnie pierwsza taka próba w obszarze polskiej literatury historyczno-wojskowej. Autor omówił przebieg działań zbrojnych między siłami portugalskimi a niemieckimi oraz ich wpływ na ustalenia konferencji międzynarodowych budujących nowy układ sił po zakończeniu Wielkiej Wojny.

Abstract: The historical literature devoted the Great War in Africa is dominated by the struggle between the German forces, superbly commanded by the initially lieutenant colonel, and finally general major Paul von Lettow-Vorbeck and units of the British Empire. The main reason of such situation is that in the east of Africa, the Germans continued fighting until the ceasefire in Western Europe in November 1918. In this narrative, there is relatively little room for a broader description of the struggles between the Germans and the Portuguese in Mozambique. The Luzytan military effort was described mainly, and at the same time disapprovingly, by the British. The impression appears that Albion deprecating the Iberian ally tried to dump a significant portion of the responsibility for the South-East Africa failures. The intention of the author of this text is to show Portuguese actions in an objective manner, not burdened with the British imperial narrative. It serves, above all, the use of Portuguese materials. This is - according to the author's knowledge the first such attempt in the area of Polish historical-military literature. The author discussed the course of armed operations between the Portuguese and German forces and their impact on the findings of international conferences building a new balance of power after the end of the Great War.

Słowa kluczowe: Mozambik, Portugalia, I wojna światowa

Keywords: Mozambique, Portugal, World War I

legendäre General Paul von Lettow-Vorbeck und sein Kampf um Ostafrika, München 1984; Ch.D. Miller, Battle for the Bundu. The First World War in East Africa, New York 1974; B. Farwell, The Great War in Africa, 1914-1918, New York 1986; R. Anderson, The Forgotten Front. The East African Campaign 1914-1918, Cheltenham 2004. 
Kiedy w 1914 roku wybuchła pierwsza wojna światowa, Portugalia Lachowała neutralność, jednakże kwestia ewentualnej partycypacji w konflikcie podzieliła opinię publiczną. Takie rozwiązanie wspierały siły polityczne skupione wokół Partii Demokratycznej. Nie przystąpiła wcześniej do wojny, głównie za sprawą kontrowersji politycznych między Lizboną a Londynem. Iberyjska republika chciała tego dokonać, odwołując się do więzów sojuszniczych w Wielką Brytanią. Ta ostatnia jednak nie była zainteresowana zaciąganiem tego rodzaju zobowiązania politycznego ${ }^{2}$.

Po wypowiedzeniu przez Wielką Brytanię wojny Niemcom (4 sierpnia 1914 roku) nasiliły się incydenty na liniach demarkacyjnych rozdzielających afrykańskie terytoria portugalskie (Mozambik, Angola) oraz niemieckie (Niemiecka Afryka Południowo-Zachodnia oraz Niemiecka Afryka Wschodnia). Był to rezultat nie tyle zaplanowanej polityki Berlina i Lizbony, ile generalnego wzrostu napięcia spowodowanego pogłoskami o rychłym wybuchu wojny. Na granicy między niemiecką Namibią a Angolą doszło w październiku 1914 roku do szeregu incydentów sprowokowanych przez Portugalczyków ${ }^{3}$, ale zagrożenie dla tamtejszych posiadłości portugalskich przestało istnieć wraz z kapitulacją sił niemieckich przed oddziałami Związku Południowej Afryki w lipcu 1915 roku4. W Mozambiku wydarzenia potoczyły się jednak inaczej, a kolonia zaabsorbowała w ciągu kolejnych lat bardzo poważne siły portugalskie.

Biorąc pod uwagę trudną sytuację polityczną i wojskową Portugalii, wysłanie do Afryki sił wzmocnienia stanowiło poważne wyzwanie dla państwa. Ostatecznie spośród około 31 tys. żołnierzy stacjonujących w metropolii zdołano przygotować i wyekwipować do służby zamorskiej około 3 tys. kombatantów. Co charakterystyczne, za organizację całego przedsięwzięcia

2 J.H. Saraiva, Krótka historia Portugalii, Kraków 2000, s. 365.

3 M. Ferreira, Portugal na Grande Guerra, Vol. II, Lisboa 1934, s. 202; wydarzenia szeroko omawia: L.M. Barosso, The First World War in Angola. The German attack on Nautila. Preparing for one war and fighting another, „Relacôes Internacionais” September 2015, issue 47, s. 127-148 (wersja cyfrowa): https://www.academia.edu/25781508/The_First_ World_War_in_Angola._The_German_attack_on_Naulila._Preparing_for_one_war_ and_fighting_another_1?auto=download, dostęp: 23.02.2018.

4 P. Brudek, Niemieckie wojska kolonialne w Afryce Wschodniej 1886-1918, Oświęcim 2016, s. 37-38. 
odpowiadało ostatecznie Ministerstwo Kolonii, nie zaś Ministerstwo Wojny. Do Mozambiku ruszyło na brytyjskim statku Durham Castle 1477 żołnierzy pod komendą podpułkownika Pedro Massano de Amorima 5 .

Po przybyciu do Mozambiku ${ }^{6}$ Pierwsze Zgrupowanie Ekspedycyjne (port. 1a Força Expedicionária) przeładowano 16 października 1914 roku w Lourenço Marques ze wspomnianego brytyjskiego transportowca na statek żeglugi lokalnej Moçambique. Pożeglował on do Pôrto Amélia (obecnie Pemba, około $350 \mathrm{~km}$ na południe od granicy z terytoriami niemieckimi). Rozładunek rozpoczął się 1 listopada. W porcie nie poczyniono żadnych przygotowań na przybycie żołnierzy, co więcej, był on zniszczony przez tajfun, który przetoczył się nad nim kilkanaście dni wcześniej. Biernością wykazał się zarówno gubernator kolonii, jak i władze miejscowe, w których wpływami cieszyli się niemieccy plantatorzy ${ }^{7}$. Pułkownik Amorim nie otrzymał rozkazów podjęcia działań zaczepnych aż do czerwca roku następnego, kiedy to uznawszy, że nie jest w stanie osiągnąć więcej, zorganizował system posterunków we wschodniej części obszaru przylegającego do terytoriów niemieckich (w pasie około $150 \mathrm{~km}$ na $900 \mathrm{~km}$ granicy) oraz zbu-

5 Walczył w Angoli, pełnił funkcję gubernatora dystryktu w Mozambiku. Odwołany do metropolii po obaleniu monarchii.

6 Według oficjalnego nazewnictwa portugalskiego Państwo Wschodniej Afryki (port. Estado da África Oriental). Mozambik jest dziewięciokrotnie większy od Portugalii. Pod względem powierzchni odpowiada on łącznym terytoriom Francji, Belgii, Holandii i Szwajcarii.

7 Miasto było siedzibą Kompanii Niassa (port. Companhia do Niassa). Przedsięwzięcia tego rodzaju powstawały pod koniec XIX w. jako reakcja na brak rodzimego kapitału pozwalającego na poważniejsze inwestycje w koloniach. W związku z tym otworzono je na zagraniczne inwestycje. Tak więc, mimo że założycielem kompanii był kupiec z Lizbony, Bernard Daupais, była ona własnością brytyjską, z czasem wykupywaną przez Niemców z sąsiedniej Tanganiki (Niemiecka Afryka Wschodnia). We władaniu kompanii pozostawał cały północny Mozambik powyżej rzeki Lurio. To właśnie kompania założyła w $1904 \mathrm{r}$. Pôrto Amélia. Prócz Kompanii Niassa w Mozambiku działały jeszcze dwie takie organizacje gospodarcze: Kompania Mozambicka (port. Companhia do Mozambique) i Kompania Zambezi (port. Companhia do Zambezi). Podstawą gospodarki plantacyjnej - a w związku z tym i funkcjonowania kompanii - był system pracy przymusowej miejscowej ludności zwany chibalo, wprowadzony po oficjalnym zniesieniu niewolnictwa w 1869 r. Kompania została przejęta przez rząd portugalski w październiku 1929 r., w ramach nowej polityki ekonomicznej opracowanej przez Salazara. 
dował 300-kilometrową drogę wraz z linią telegraficzną przez płaskowyż Makonde między Pôrto Amélia a Mocímboado Rovuma. W listopadzie de Amorim został odwołany. Straty pierwszego zgrupowania na skutek chorób osiągnęły $20 \%$ stanu wyjściowego ${ }^{8}$.

Portugalczycy wysłali do Mozambiku w sierpniu 1915 roku kolejne wzmocnienie (2ª Força Expedicionária), łącznie 1,5 tys. żołnierzy zorganizowanych w batalion piechoty, baterię artylerii górskiej, baterię karabinów maszynowych, szwadron kawalerii i pododdział saperski, dowodzonych przez politycznie ustosunkowanego, ale pozbawionego doświadczenia majora José Luiza de Moura Mendesa9. Siły te przybyły do kolonii 7 listopada. Ambicją Lizbony było odzyskanie, kilkukrotnie już wspomnianego, trójkąta Kionga (Quionga), obszaru o powierzchni około tysiąca $\mathrm{km}^{2}$ obsadzonego przez Niemców w 1894 roku, położonego między południowym brzegiem rzeki Rovuma (Ruvama, Ruwama) a oceanem. Do 9 marca 1916 roku, kiedy to Niemcy wypowiedziały wojnę Portugaliii ${ }^{10}$, nie rozpoczęto tam jednak działań zbrojnych, a po wybuchu wojny oczekiwano na trzeci rzut sił wzmocnienia przygotowywany w metropolii.

Siły portugalskie stacjonujące w Pôrto Amélia borykały się w tym czasie z olbrzymimi problemami, wynikającymi głównie z malarycznego klimatu i nieprzestrzegania podstawowych standardów sanitarnych. Można było odnieść wrażenie, że armia bądź to zapomniała o wszystkich doświadczeniach zdobytych w czasie kilkuset lat operowania na terytoriach zamorskich, bądź zatrzymała się w rozwoju 150 lat wcześniej i od połowy XVIII wieku nie przyswajała już nowej wiedzy, będącej doświadczeniem innych nacji. Portugalczycy zmagali się z malarią, gruźlicą, gorączkami tropikalnymi i syfilisem. Latryny były niezabezpieczone, więc fekalia rozlewały

8 E. Paice, Tip \& Run, The Untold Tragedy of the Great War in Africa, London 2008, s. 141 .

${ }^{9}$ F. Rita, The First World War in Mozambique (1914-1918), http://www.portugalgrandeguerra.defesa.pt/Documents/THE\%20FIRST\%20WORLD\%20WAR\%20 IN\%20MOZAMBIQUE\%20(1914-1918).pdf, dostęp: 23.02.2018.

${ }_{10}$ Powodem wypowiedzenia wojny przez Niemcy 9 marca $1916 r$., zaś przez Austro-Wegry 15 marca, byto zajęcie 23 lutego statków obu państw korzystajacych w portach neutralnej wówczas Portugalii z prawa azylu; T. Wituch, Historia Portugalii w XX wieku, Pułtusk 2000, s. 59. 
się w bezpośrednim sąsiedztwie rejonów kwaterowania, żołnierze odmawiali picia przegotowanej wody, bo była cieplejsza niż czerpana z rzek i strumieni, ponadto miała metaliczny posmak zbiorników, a przyjmowanie chininy było wśród żołnierzy z metropolii uważane za niemęskie ${ }^{11}$. W wymiarze taktycznym i operacyjnym zasadniczym błędem było niezorganizowanie systemu rozpoznania. Wiadomości o przeciwniku pozyskiwano z pogłosek krążących wśród miejscowych żołnierzy, a poza kilkoma liniami telegraficznymi, często zresztą zrywanymi, nie funkcjonowała łączność inna niż oparta na posłańcach, nie posiadano map terenu i nie podjęto wysiłków, by takowe stworzyć (głównie z powodu braku kompetentnych oficerów i podoficerów). Szkolenie funkcjonowało szczątkowo i sprowadzało się głównie do musztry formalnej. Żołnierze byli więc apatyczni, zdemoralizowani, pozbawieni ducha zaczepnego. Do tego trzeba jeszcze dodać niską jakość uzbrojenia. Część artylerii posiadała na przykład armaty górskie Kruppa z lufami odlanymi z brązu wprowadzone do eksploatacji w 1882 roku (BEM 7 cm m/882), kartaczownice Montigny'ego-Reffyego i Nordenfelta, a także rewolwerowe armaty Hotchkissa ${ }^{12}$ kalibru $37 \mathrm{~mm}$. Było to już uzbrojenie w znacznym stopniu anachroniczne, nawet jeżeli pozostawało sprawne. W zakresie broni indywidualnej sytuacja przedstawiała się nieco lepiej. Regulaminowym karabinem piechoty był 6,5 mm Mauser-Vergueiro (oznaczenie wojskowe Espingarda 6,5 mm m/1904) ${ }^{13}$, ale w pododdziałach z zaciągu lokalnego występował nadal Kropatschek m/1886 (Espingarda de Infantaria $8 \mathrm{~mm} \mathrm{~m} / 1886$ ) w różnych wersjach (jego zaletą była możliwość strzelania starszą amunicją, wykorzystującą proch znajdujący w dużej ilości w lokalnych magazynach). Oficerowie i podoficerowie wykorzystywali

11 J.P. Cann, Mozambique, German East Africa and the Great War, "Small Wars \& Insurgencies" 2001, nr 12, s. 126; http://docplayer.net/65465324-Mozambique-germaneast-africa-and-the-great-war.html, dostęp: 12.02.2018.

12 M. de Sousa, As Principais Reorganizaçóes do Exército do Século XVIII ao Século XXI. Reflexos para a Artilharia, Amadora 2008, s. 19.

13 Broń, na podstawie niemieckiego Mausera 1898 z zapożyczeniem rozwiązań z karabinów Gewehr 1888 oraz Gewehr 1888 i Mannlicher-Schönauer, została zaprojektowana przez oficera piechoty José Alberto Vergueiro. Wytwarzały ją zakłady Deutsche Waffen und Munitionsfabriken (DWM). 
różne typy rewolwerów i pistoletów, bardzo pożądany (wręcz snobistyczny, kupowany za prywatne środki) był niemiecki 7,63 mm Mauser C96 ${ }^{14}$.

Tymczasem w marcu 1916 roku Niemcy ewakuowali znaczny obszar, co umożliwiło Portugalczykom zajęcie go bez jednego wystrzału. Grupa wydzielona, dowodzona przez majora da Silvera, złożona z kompanii piechoty i baterii artylerii górskiej, została przetransportowana na statku $\mathrm{Lu}$ abo do Palma. Tam dołączyła kompania piechoty z miejscowego zaciągu. Major da Silvera pomaszerował następnie wzdłuż wybrzeża do Quionga (12 km), którą to miejscowość zajęto 10 kwietnia, zastając tam jedynie porzucone okopy. $23 \mathrm{kwietnia}$ pozostałe siły portugalskie zostały przetransportowane morzem, na parowcu Limba, do Palma. Pozycje portugalskie oparły się zatem o południowy brzeg rzeki Rovuma. Dalej na zachód, aż do jeziora Niassa, ciągnęła się linia słabo obsadzonych posterunków obserwacyjnych. Ich obsługi zdawały sobie sprawę, że w przypadku problemów nie mogą liczyć na pomoc, w związku z czym nagminne stało się ich porzucanie na skutek pojawienia się najmniejszych symptomów zagrożenia ze strony Niemców ${ }^{15}$.

Gubernator Álvaro de Castro podjął wiosną znaczny wysiłek, by wesprzeć siły na północy bez konieczności oczekiwania na kolejne oddziały z metropolii. Udało mu się zorganizować, na bazie Gwardii Republikańskiej z Lourenço Marques, kompanię piechoty złożoną z Europejczyków i dwie kompanie piechoty z lokalnego zaciągu, a także baterię artylerii górskiej z archaicznymi armatami $\mathrm{m} / 882$. Pododdziały te, prowadzone przez de Castro, ruszyły morzem na północ 18 maja ${ }^{16}$.

27 maja 1916 roku Mendes, otrzymawszy posiłki i zapewniwszy sobie wsparcie przybyłych z Lourenço Marques: krążownika Adamastor oraz kanonierki Chaimite, podjął próbę przeprawienia się przez Rovumę w rejonie jej ujścia do Oceanu Indyjskiego. Akcja była źle zaplanowana i fatalnie przeprowadzona.Zaniedbanozarówno przeprowadzenierozpoznania nurtu, jaki północnego brzegu rzeki, nie zgromadzono zapasów wody, nie zadbano o zgromadzenie rezerw amunicji i środków przeprawowych. Zamysł, opierający się

\footnotetext{
14 M. de Sousa, As Principais Reorganizaçôes..., s. 20-12.

15 J. Cann, op. cit., s. 129.

16 Ibidem, s. 127.
} 
na przekonaniu, że Niemców nad Rovumą po prostu nie ma (mimo że 23 maja próba lądowania na północnym brzegu podjęta samodzielnie przez marynarkę została udaremniona ogniem karabinu maszynowego), przewidywał przeprawienie się piechoty na drugą stronę rzeki łodziami obsadzonymi przez marynarzy z krążownika ${ }^{17}$.

Portugalczycy natknęli się na ogień niemieckich ubezpieczeń, część łodzi osiadła na piaskowych łachach rozciągających się wzdłuż nurtu, z powodu brunatnego koloru wody niewidocznych z brzegu, a ich osady i przewożony desant zdziesiątkował celny ogień niemiecki. Zginęło 22 Portugalczyków, w tym 11 marynarzy z krążownika Adamstor, a ośmiu dostało się do niewoli. Najistotniejsze było jednak to, że oddziały luzytańskie ${ }^{18}$, których morale wcześniej było już bardzo niskie, w następstwie wydarzeń 27 maja utraciły zdolność do jakiejkolwiek akcji zaczepnej, mimo że miały nad Niemcami znaczną przewagę liczebną. Tymczasem przeciwnicy Portugalczyków nie zamierzali poprzestawać na zerwaniu próby forsowania granicznej rzeki. Przez następne trzy miesiące atakowane były portugalskie posterunki. Doprowadziło to w praktyce do ich unicestwienia. Straty wyniosły około 600 żołnierzy, z tego 480, w większości z lokalnego zaciaggu, po prostu zniknęło bez śladu. W ten sposób zabezpieczono południową granicę, co, biorąc pod uwagę ciągły nacisk na oddziały Lettow-Vorbecka ze strony sił brytyjskich oraz belgijskich, było niebagatelnym sukcesem ${ }^{19}$.

Trzeci rzut sił wzmocnienia dotarł do Mozambiku między końcem maja a połową lipca 1916 roku. Składał się z ponad 4,9 tys. żołnierzy (trzy bataliony piechoty, trzy baterie artylerii górskiej, kompania saperów

17 A História do NRP Adamastor, http://www.momentosdehistoria.com/001grande_guerra/001-01-marinha/001-01-05-marinha_guerra/001-01-05-03-nrp_adamastor.html, dostęp: 12.03.2018; Portuguese Navy (Portugal), Other Fighting Ships, Chaimite Gunboat (1898), http://www.navypedia.org/ships/portugal/pr_of_chaimite. htm, dostęp: 12.03.2018.

18 Nazwę Luzytania (łac. Lusitania, Hispania Lusitania) nosiła prowincja rzymska położonej na obszarze dzisiejszej Portugalii, którą zamieszkiwało plemię Luzytan. W powszechnej świadomości jako synonim Portugalii upowszechnił ją Luís Vaz de Camóes, nadając narodowemu eposowi tytuł Luzjady (Os Lusiadas, a według nowszego przekładu polskiego Luzytanie).

19 J. Cann, op. cit., s. 129. 
i pontonierów z plutonem telegraficznym, dwie kompanie Gwardii Republikańskiej, pododdział medyczny, pododdział administracyjny, kompania karna, 900 koni i mułów), dowodzonych przez generała José Césara Ferreirę Gila ${ }^{20}$. Wtedy to Portugalczycy, dysponując sześcioma batalionami europejskiej piechoty wraz z pododdziałami wsparcia i zabezpieczenia, wspieranymi przez 10 kompanii zorganizowanych z żołnierzy z miejscowego zaciągu, zaczęli ponownie rozważać marsz na północny zachód, w kierunku Płaskowyżu Makonde i dalej ku jezioru Niassa, gdzie zamierzano połączyć się z oddziałami brytyjskimi i belgijskimi. Biorąc pod uwagę kondycję psychofizyczną oddziałów, było to założenie ze wszech miar optymistyczne. Alternatywą były działania wzdłuż brzegu Oceanu Indyjskiego. W takim przypadku zadaniem bliższym miała być miejscowość Mikindani (z przystanią około $50 \mathrm{~km}$ na północ od ujścia Rovumy), położona nad zatoką o tej samej nazwie, a następnie Lindi (około $50 \mathrm{~km}$ dalej na północ) oraz Kilwa (około $150 \mathrm{~km}$ na północ od granicy). Miejscowości te stanowiły elementy niemieckiego systemu zaopatrywania sił operujących na południu Tanganiki. Na pierwszy rzut oka był to dogodny kierunek, gdyż umożliwiał zaopatrywanie sił morzem (z której to sposobności korzystali Niemcy), choć wymuszał forsowanie uchodzących do oceanu rzek. Taką właśnie propozycję przedstawił gubernator generalny Mozambiku Álvaro Xavier de Castro. Pogłębiona analiza wykazała jednak pełną życzeniowość przytoczonego zamiaru. Portugalczycy, ze względu na brak środków transportu i zapasów, nie mieli możliwości wtargnięcia 250-300km w głąb niemieckiej kolonii, pomijając już kwestię nader wstrzemięźliwego stosunku do owych zamiarów ich brytyjskiego sojusznika, niezainteresowanego rozbudzaniem afrykańskich ambicji Lizbony.

20 Oficer silnie zaangażowany politycznie, przekonany republikanin, w październiku 1913 r. uczestniczył w pacyfikacji rojalistycznego powstania, które wybuchło w rejonie Viana de Castello (prowincja Minho), następnie dowodził 29. pułkiem piechoty uczestniczącym w puczu 1915 r., odniósł wówczas ranę. Po tych wydarzeniach został awansowany do stopnia generała. Przed wysłaniem do Mozambiku nigdy nie dowodził w polu. Pierwotnie na czele oddziałów wysyłanych do Mozambiku zamierzano postawić doświadczonego „Afrykańczyka”, pułkownika Tomása António Garcię Rosado. Nie można było jednak ufać oficerowi, który mimo swych kompetencji otrzymał najwyższe portugalskie odznaczenie, Order Wieży i Miecza, z rąk zastrzelonego w 1908 r. króla Karola (Carlosa) I. 
Tymczasem inicjatywą wykazywali się Niemcy. 1 sierpnia 1916 roku został zaatakowany ważny, leżący na skrzyżowaniu szlaków komunikacyjnych, posterunek Nangadi, broniony przez kompanię tubylczej piechoty wzmocnioną 16 policjantami. Atak został odparty, co nie może dziwić, gdyż na całym odcinku południowej granicy Niemcy mieli tylko dwie kompanie, więc musieli działać niesłychanie ostrożnie i by nie narażać się na straty.

Wraz z wtargnięciem Niemców do Mozambiku doszło do wybuchu fali niepokojów wśród miejscowej ludności. Była ona wywołana wyjątkowo brutalnym traktowaniem lokalnej populacji przez europejskich zarządców. Szczególnie złą sławę zdobyła założona w 1905 roku Empresa Agrícola do Lulgela. Początkowo trudniła się głównie rekrutacją robotników, którzy następnie wysyłani byli do pracy przy uprawie kakao na Wyspie Świętego Tomasza. Tamtejsze plantacje należały do jednego z udziałowców firmy. Od 1915 roku rozpoczęto, z dużym sukcesem, uprawę herbaty. Wiązało się to jednak ze zwiększeniem obciążeń lokalnych mieszkańców. Nad wyraz niekorzystną opinię zdobył sobie szwajcarski zarządca René Vuilleumeir ${ }^{21}$. Wodzowie szczepów, zwani muenes lub samaçosas, zamieszkującej tam grupy etno-językowej Macua-Lomué (Makua, Makhuwa)22 z własnej inicjatywy zgłaszali się do Niemców, oferując pomoc i przyłączenie się do nich, von Lettow-Vorbeck nie przystał na to, obawiając się uzbrojenia wojowników populacji, której nie ufał ${ }^{23}$. Co interesujące, to właśnie na terenach ogarniętych niepokojami w 1918 roku w 1964 roku najsilniejsze wsparcie uzyskali walczący z Portugalczykami partyzanci z organizacji Frontu Wyzwolenia Mozambiku (Frente de Libertação de Moçambique, FRELIMO) ${ }^{24}$.

W Pôrto Amélia nie było możliwości zakwaterowania sił trzeciego rzutu, dlatego żołnierzy wyładowano w Palma (350 km dalej na północ), na terenie trójkąta Kionga, z którego wcześniej wycofali się Niemcy. Nie było

21 A. Keese, Unlike the Other Whites? The Swiss in Mozambique under colonialism, [w:] Imperial Migrations: Colonial Communities and Diaspora in the Portuguese World, red. E. Moriner-Genoud, M. Cahen, Houndmills 2012, s. 74.

22 Najsilniejsza liczebnie grupa plemienna w Mozambiku, zamieszkująca na północ od Zambezi, również na terytorium obecnej Tanzanii. W około $70 \%$ było w owym czasie animistami, pozostali - zwłaszcza w pasie nadbrzeżnym - wyznawali islam.

23 P. Brudek, Niemieckie wojska..., s. 129, 166.

24 A. Keese, op. cit., s. 75. 
tam nie tylko żadnej infrastruktury koszarowej, ale nawet przystani, więc żołnierze schodzili z łodzi na nieprzygotowany brzeg, zaś zapasy składowano pod plandekami, tracąc $\mathrm{w}$ ten sposób część środków przywiezionych z niemałym wysiłkiem z Europy. Generał César Ferreira Gil był świadom kondycji swoich żołnierzy i domagał się od Lizbony dalszych dostaw zaopatrzenia, a przede wszystkim czasu na aklimatyzację i szkolenie. Nie otrzymał ani jednego, ani drugiego. Mimo to zdołał zorganizować trzy kolumny, z których pierwsza przekroczyła 18 września Rovumę u ujścia, a dwie kolejne 19 września w górze jej biegu, w okolicy Mocimboa. Kolumna wschodnia posuwała się na północ, nie napotykając oporu, zaś w ślad za nią przerzuceni wcześniej do Pôrto Amélia żołnierze brytyjscy obsadzali przystanie na północ od ujścia Rovumy. Kolumna zachodnia dotarła 4 października do Maúta (Mahuta), gdzie pododdział niemiecki stawił opór i zmusił Portugalczyków do wycofania się ${ }^{25}$.

Niedoświadczony żołnierz był po kilkunastu dniach działań w trudnym terenie wyczerpany pod względem fizycznym i psychicznym, a na kondycję Portugalczyków dodatkowo wpływały negatywnie ustawiczne problemy zaopatrzeniowe. W rezultacie zdołali oni zająć jedynie opuszczone pozycje niemieckie w Nevala, położone zaledwie około $15 \mathrm{~km}$ na północ od Rovumy. Generał Gil uznał jednak, że kolumna zachodnia powinna prowadzić pościg za wycofującymi się Niemcami i wzmocnił ją 23 oficerami (wśród których był wyznaczony na nowego dowódcę major Leopold da Silva), 746 żołnierzami i 330 tragarzami. Silva poprowadził swoich ludzi na północ, ale rychło natknął się na linię ubezpieczeń przeciwnika i poległ, usiłując poderwać podwładnych do ataku. Przekreśliło to zamiary jakiegokolwiek dalszego pościgu, do którego Portugalczycy okazali się po prostu niezdolni.

Tymczasem Niemcy przygotowywali się do kontrataku. Za tymi działaniami stał oficer niezwykle dynamiczny i obdarzony inicjatywą, Max Loof, były dowódca krążownika Königsberg, zatopionego przez Brytyjczyków

25 R. Marques, Os Fantasmas do Rovuma, A epopeia dos soldados portugesesem Áfricana I Guerra Mundial, Lisboa 2012, s. 97. 
15 lipca 1915 roku w delcie rzeki Rufiji ${ }^{26}$. Na początku działań miał on pod swoimi rozkazami trzy kompanie askarisów z miejscowego zaciągu, ale obecnie wzmocniono go kolejnymi dwoma kompaniami oraz pojedynczą 105-milimetrową armatą zdemontowaną z zatopionego krążownika Königsberg, a zamontowaną na lawecie polowej ${ }^{27}$. Dysponując pięcioma kompaniami tubylczej piechoty i wykorzystując przewagę znajomości terenu oraz ruchliwości taktycznej, Loof mógł sobie pozwolić na podjęcie próby zatrzymania portugalskiej kolumny zachodniej. Jego oddziały ruszyły ku Nevala 19 listopada, a trzy dni później przeciwnik został zablokowany i odcięty od dostaw zaopatrzenia, a przede wszystkim od źródeł słodkiej wody, o które toczyły się zacięte walki. Równocześnie rozpoczął się niezbyt intensywny, ale osłabiający morale Portugalczyków ostrzał artyleryjski. Niemiecka morska armata miała przy tym niekwestionowaną przewagę zasięgu nad armatami polowymi przeciwnika kalibru $70 \mathrm{~mm}$ (Schneider-Canet 1906/1911). W takiej sytuacji rozpoczęty 28 listopada odwrót rychło przeobraził się w paniczną ucieczkę. Portugalczycy porzucili cztery armaty polowe, siedem karabinów maszynowych, dwa samochody i 45 wozów z zaopatrzeniem. Dla odciętych od dostaw Niemców była to zdobycz o kluczowym znaczeniu ${ }^{28}$. Po dwóch dniach zdezorganizowane i niezdolne do działania pododdziały portugalskie dotarły nad Rovumę i rozpoczęły przeprawę. Loof podążył za nimi, zajmując ponownie wszystkie wcześniej utracone pozycje. Portugalczycy usiłowali zreorganizować swoje siły w Nangade (około $15 \mathrm{~km}$ na północ od południowego brzegu Rovumy), ale Loof dotarł tam 1 grudnia i uczynił cały zamiar bezprzedmiotowym. Niemcy najpierw ostrzelali miejscowość ogniem artylerii, a następ-

26 Doszło do tego w delcie rzeki Rufidżi po trwającej 255 dni blokadzie, która zaangażowała 27 brytyjskich okrętów. W ostatecznej rozprawie z jednym niemieckim lekkim krążownikiem brały udział ze strony brytyjskiej: pancernik (pre-dreadnought), cztery krążowniki, dwa monitory, cztery uzbrojone wielorybnicze statki łowcze, baza wodnosamolotów oraz 10 samolotów. Por. A. Perepeczko, Wojna samotnych krążowników, Warszawa 1997, s. 113-121.

27 Cztery lawety dostarczył do Afryki transportowiec Marie, który mimo brytyjskiej blokady dotarł 16 marca 1916 r. do zatoki Sudi (ujście dwóch strumieni między Mikindani i Lindi).

28 J. Cann, op. cit., s. 132. 
nie - po ucieczce Portugalczyków - puścili ją z dymem. Tym samym Loof znalazł się około $100 \mathrm{~km}$ na zachód od Palma - najważniejszego punktu oparcia przeciwnika na wybrzeżu Oceanu Indyjskiego. W następnych dniach Niemcy zapuścili się na zachód, w kierunku Mocimboa do Rovuma, która to miejscowość została ewakuowana, oraz na wschód ku Pundanhar (w połowie drogi między Nangade a Palma). Wśród Portugalczyków pojawiły się wówczas obawy, że agresywny niemiecki dowódca skieruje się do oceanu, co dawałoby mu możliwość całkowitego zniszczenia ich sił na północy Mozambiku. Nie zdawano sobie przy tym sprawy, jak słabe były siły Loofa. On sam był świadomy istniejących ograniczeń, i kiedy w połowie grudnia zaczęły padać obfite deszcze, co skutkowało wzrostem poziomu wód, wycofał się za Rovumę. Niemiecki sukces był niezaprzeczalny. Mimo przewagi liczebnej przeciwnika nie tylko zmuszono go do odwrotu, ale rozbito, pozbawiając na długie miesiące możliwości działania zaczepnego ${ }^{29}$.

Wydarzenia z listopada 1916 roku wstrząsnęły Portugalczykami. Generał Gil złożył dowództwo, jakoby z „powodu choroby”, i wrócił do kraju, zaś komendę objął generalny gubernator Mozambiku Álvaro Xavier de Castro $^{30}$. Zarówno z uwagi na własne kompetencje, jak i kondycję podległych mu wojsk mógł on co najwyżej myśleć o utrzymaniu systemu posterunków obserwacyjnych nad Rovumą i mieć nadzieję, że Niemcy powstrzymają się od działań zaczepnych przeciwko Mozambikowi. Rachuby te sprawdzały się przez kilka następnych miesięcy. Siły von Lettow-Vorbecka przez cały czas naciskane przez Brytyjczyków, współdziałających z Belgami, nie dawały się osaczyć i umiejętnie wymykały się przeciwnikowi. Portugalczycy w owym kontredansie już jednak nie uczestniczyli. Meldunki, płynące z Mozambiku do Lizbony, nie pozostawiały wątpliwości co do konieczności kolejnego wzmocnienia sił w kolonii. Miejscowy żołnierz, głęboko zdemoralizowany niepowodzeniami, mógł być co najwyżej, a i to w ograniczonym stopniu,

29 Ibidem, s. 133, Namaca, http://www.momentosdehistoria.com/MH_05_02_01_ Exercito.htm, dostęp: 03.10.2018.

30 Nie był oficerem liniowym, ale członkiem korpusu administracyjnego sił zbrojnych, z wykształcenia prawnikiem, a także absolwentem Szkoły Kolonialnej (Escola Colonial). Udzielał się politycznie po stronie republikańskiej. Przed objęciem funkcji w Mozambiku był ministrem sprawiedliwości, a po powrocie do kraju sprawował funkcję ministra kolonii, ministra spraw wewnętrznych i premiera. 
wsparciem dla nowych sił przybyłych z metropolii. Portugalia podjęła więc kolejny wysiłek mobilizacyjny i przystąpiła do organizacji czwartego rzutu sił wzmocnienia. Ostatecznie liczył on około 6 tys. żołnierzy. Jego rdzeniem były trzy bataliony piechoty, dwie baterie artylerii górskiej (14 dział), dwie baterie karabinów maszynowych (42 karabiny maszynowe różnych typów) i kompania saperów, wsparte pododdziałami zabezpieczenia oraz służbami. Załadunek pododdziałów czwartego rzutu rozpoczął się w Lizbonie w lipcu 1917 roku, a zaczęły one napływać do Mocímboa da Praia $(80 \mathrm{~km}$ na południe od Palma) 12 września. Przerzut zakończył się pod koniec października. Na czele wysłanych do Afryki sił stanął pułkownik Tomás de Sousa Rosa $^{31}$, przybyły do Mozambiku z pierwszym transportem ${ }^{32}$.

Wysłanie tak zwanej 4. Ekspedycji związane było z przebiegiem działań przeciwko siłom Lettow-Vorbecka, które powoli, lecz nieustannie przemieszczały się na południe. Prognozy alianckie zakładały, że najbardziej prawdopodobnym posunięciem Niemców wobec odcinania ich od bazy aprowizacyjnej będzie próba przeniesienia działań na teren, niedotkniętego jeszcze działaniami na większą skalę, portugalskiego Mozambiku. Przewidywania te potwierdził dowódca Schutztruppe, wysyłając w kwietniu 1917 roku cztery kompanie dowodzone przez majora Willibalda von Stuemeraz Tunduru na południe. Wydzielony oddział, pokonawszy około 80 km, przekroczył Rovumę 16 kwietnia. Na południowym brzegu rzeki napotkano bardzo słaby opór ${ }^{33}$. Portugalczycy zostali całkowicie zaskoczeni. Do końca kwietnia Niemcy spenetrowali znaczny obszar, zapuszczając się ponad $250 \mathrm{~km}$ w głąb portugalskiej kolonii i zdobywając Luamblę (nad rzeką o tej samej nazwie), a następnie powrócili z bogatymi łupami do swoich

31 Kolejny oficer o zdecydowanie republikańskich poglądach. Kampania mozambicka była dla niego pierwszym dowództwem polowym. Wyznaczenie na stanowisko wiązało się z powrotem do służby czynnej, z której urlopowany był w 1915 r., po uzyskaniu mandatu deputowanego do parlamentu wyłonionego w następstwie puczu 15 maja.

32 A Questão de Serra Mecula (1917), http://www.momentosdehistoria.com/ MH_05_02_04_Exercito.htm, dostęp: 03.10.2018.

${ }_{33}$ H. Moyse-Bartlett, The King's African Rifles, A Study in the Military History of East and Central Africa, 1900-1945, Volume 1, b.m., s. 374. 
sił głównych obozujących nad jeziorem Itungi (północno-zachodnia część jeziora Malawi, zwana zatoką Wissmanna w dzisiejszej Tanzanii ${ }^{34}$.

Po wyokrętowaniu swoich pododdziałów w Mocímboa da Praia pułkownik Souza Rosa rozmieścił we wrześniu swoje stanowisko dowodzenia w Chomba w odległości około $140 \mathrm{~km}$ od wybrzeża. Miało to jedną zaletę - rejon ten wyniesiony na około $700 \mathrm{~m}$ n.p.m. wolny jest od malarii. Z kolei plan portugalskiego dowódcy można uznać za klasyczny przykład zastosowania podręcznikowego modelu do nietypowej wojny. Postanowił on rozciągnąć swoje siły wzdłuż Rovumy, a po określeniu kierunku posuwania się przeciwnika osaczyć go, wykonując manewr po własnych liniach wewnętrznych. Słabych punktów owego planu było kilka. Kluczowe było jednak to, że nie istniała możliwość prowadzenia skutecznego rozpoznania i przekazywania jego rezultatów, a zatem również efektywnego dowodzenia przy rozproszeniu podległych sił w pasie o szerokości około $120 \mathrm{~km}$ i głębokości 40-60 km³.

Początkowo na północnym brzegu Rovumy Niemcy utrzymywali tylko ubezpieczenia w sile czterech europejskich podoficerów i 48 żołnierzy z miejscowego zaciągu, których mogła wesprzeć rezerwa w postaci rozmieszczonych dalej na północ dwóch kompanii askarisów. W miarę wzmagania się nacisku ze strony wojsk Wspólnoty Brytyjskiej na główne siły niemieckie sytuacja zaczęła się zmieniać. W listopadzie von Lettow przeprowadził reorganizację sił, zmniejszając ich liczebność do 38 oficerów i 230 podoficerów europejskich oraz 1,7 tys. żołnierzy miejscowych wraz z liczącą około 5 tys. osób kolumną złożoną z tragarzy i służących. Miało to zwiększyć ruchliwość jego oddziałów przed planowanym wtargnięciem

34 P. Brudek, Afryka Wschodnia 1914-1918, Warszawa 2008, s. 174.

35 Można nadmienić, że początkowo Souza Rosa chciał atakować przez Rovumę i sugerował brytyjskiemu dowódcy, generałowi van Deventerowi, by jego wojska pozostały na stanowiskach, podczas gdy Portugalczycy będą spychać Niemców w ich kierunku. Zamysły te - pomijając wykonalność - zostały zablokowane przez Lizbonę. Rząd portugalski działał pod naciskiem Brytyjczyków, którzy nie chcieli, by ich sojusznicy wkraczali na teren kolonii niemieckiej, gdyż mogłoby to stanowić uzasadnienie późniejszych roszczeń terytorialnych. 
do Mozambiku. Niemcy, którzy 15 listopada przekroczyli graniczną rzekę, mieli 37 karabinów maszynowych i dwie armaty górskie ${ }^{36}$.

Sousa Rosa rozmieścił na pozycjach wzdłuż Rovumy około 3 tys. żołnierzy uszykowanych $\mathrm{w}$ następującym ugrupowaniu ${ }^{37}$ :

a) punktu oporu - komponent statyczny mający dostarczyć precyzyjnych informacji o oddziałach niemieckich i skanalizować ich ruch:

- Nagomano - dwie kompanie miejscowe, sześć karabinów maszynowych,

- Serra Mekula - dwa plutony miejscowe, bateria karabinów maszynowych,

- Nangur - pluton miejscowy,

- Montes Macolos - kompania miejscowa,

- Mocimboa do Rovuma - trzy kompanie miejscowe, bateria artylerii, bateria karabinów maszynowych,

b) kolumny manewrowe - komponent dynamiczny odpowiedzialny za otoczenie i zniszczenie sił przeciwnika:

- Nanguar - dwie kompanie miejscowe, bateria karabinów maszynowych,

- Mocimboa do Rovuma - siedem kompanii miejscowych, bateria artylerii, trzy kompanie karabinów maszynowych,

- Negomano - cztery kompanie miejscowe, bateria karabinów maszynowych,

- Nanguadi - cztery kompanie miejscowe, bateria karabinów maszynowych, bateria artylerii.

Portugalczycy już w fazie rozmieszczania sił borykali się z olbrzymimi problemami logistycznymi. Tylko oddziały dyslokowane w Negomano, gdzie Lugenda wpada do Rovumy, potrzebowały 9 ton żywności dziennie, zaś transport był realizowany w trudnym terenie tylko przy wykorzystaniu tragarzy (wymagało to około 300 ludzi, którzy również konsumowali

36 A Questão de Negomano (1917), http://www.momentosdehistoria.com/MH_ 05_02_03_Exercito.htm, dostęp: 01.03.2018.

37 Ibidem. 
żywność i wodę). Oddziały portugalskie zajęły nakazane pozycje między 13 a 15 października ${ }^{38}$.

Tymczasem już 3 października brytyjski oficer łącznikowy, major Azambuja Martins, poinformował Portugalczyków, że von Lettow-Vorbeck znajduje się w rejonie Lukulendi z 12 kompaniami piechoty i dwoma działami. Odległość między siłami niemieckimi a portugalskimi wynosiła więc około $250 \mathrm{~km}$, co tym drugim dawało złudne poczucie bezpieczeństwa. W dniach 15 i 21 października Niemcy pobili Brytyjskie siły na północ od Rovumy i generał van Deventer poinformował Sousę Rosę, że Niemcy kierują się na południe. Ten w reakcji wzmocnił pozycje w Rovuma Mocimboa.

16 listopada dowódca sił rozmieszczonych w Negomano, major João Teixeira Pinto ${ }^{39}$, otrzymał informację z dowództwa, że siły niemieckie kierują się w stronę jego pozycji i znajdują się około $120 \mathrm{~km}$ na północ. Równocześnie do Negomano skierowane zostały dwie kompanie z Nampacheco (major Costa Pereira). Rozpoczęto też organizowanie silnej kolumny złożonej z trzech kompanii piechoty, baterii karabinów maszynowych, baterii artylerii i szwadronu kawalerii, która miała wyruszyć do Negomano z Rovuma Mocimboa, ale nie dotarła do miejsca przeznaczenia przed Niemcami. 20 listopada van Deventer potwierdził wcześniej przekazane informacje, wskazując, że intencją przeciwnika, biorąc pod uwagę jego dotychczasowe manewry, jest bez wątpienia wkroczenie do Mozambiku. Jako miejsce prawdopodobne forsowania Rovumy wskazał odcinek między Lidede a Mocimboa do Rovuma, co nie miało się potwierdzić. Pięć dni później Niemcy wkroczyli na teren portugalskiej kolonii ${ }^{40}$.

Tymczasem 24 listopada Texeira Pinto, który dowodził już wówczas około tysiącem żołnierzy, otrzymał informację od przełożonego, że

38 Ibidem.

39 Doświadczony oficer kolonialny. Jego ojciec, Alexandre Serpa Pinto, prowadził w latach osiemdziesiątych XIX w. eksplorację afrykańskiego interioru. João pełnił służbę najpierw w Angoli (1902-1911), a następnie w Gwinei, gdzie zdobył przydomek „diabelskiego kapitana” (port. Capitão Diabo), z racji zmuszania opornych plemion do uległości metodą spalonej ziemi. Odegrał kluczową rolę w pacyfikacji regionu Oio. W 1916 r. został skierowany do Mozambiku.

40 M. Ferreira, Viriato de Lacerna, Lisboa 1939, s. 43. 
przeciwnik operuje około $70 \mathrm{~km}$ od jego pozycji. Jak na doświadczonego żołnierza wojującego wcześniej w Gwinei, major zachowywał się niefrasobliwie. Informacja ze sztabu uspokoiła go tak bardzo, że zaniechał prowadzenia rozpoznania i wystawienia dalekich ubezpieczeń. Niemcy zaatakowali następnego dnia około południa, rozpoczynając działania z marszu siłami pięciu kompanii wspartych ogniem pojedynczej armaty. Pozwoliło to na uzyskanie zaskoczenia. Portugalczycy utrzymywali pozycje przez około dwie godziny, ale następnie 25. i 27. kompania tubylcza poszły w rozsypkę. Uciekający, jak zwykle w takich sytuacjach bywa, pociągnęli za sobą kolejnych żołnierzy i po krótkim czasie większość obrońców umykała przed Niemcami, którzy wprowadzili do działań kolejne dwie kompanie. Tym samym pochwycili oni kilkanaście dziesiątek jeńców. Po stronie portugalskiej padło pięciu oficerów, 21 podoficerów i europejskich specjalistów oraz 162 czarnych piechurów. Do niewoli dostało się około 30 białych i około 140 miejscowych (w tym 65 rannych). Von Lettow zdobył 250 tys. sztuk amunicji, sześć karabinów maszynowych i 30 koni, a także, co w tamtejszych warunkach było istotne, kilkadziesiąt słojów z chininą ${ }^{41}$. Sousa Rosa stracił ponad jedną piątą stanu wyjściowego i znaczne ilości deficytowego zaopatrzenia.

Brytyjczycy zaczęli w tym czasie negocjacje w Portugalczykami, dotyczące wprowadzenia ich wojsk do Mozambiku, ale nie przez Rovumę, lecz morzem, przez Pôrto Amélia. Następnie, po przemarszu w głąb lądu, zamierzano zaatakować Niemców od wschodu lub od wschodu i południa. Tymczasem jednak van Deventer nie śpieszył się z podejmowaniem pościgu. W jego rękach znajdowała się wszakże cała Niemiecka Afryka Wschodnia, zaś przeciwnik żywił się kosztem portugalskiego alianta. Tymczasem jego linie zaopatrzeniowe sięgające aż Dar es Saalam niebezpiecznie się rozciągały.

Niemcy operowali swobodnie w obrębie portugalskiej kolonii. Problemem okazało się zdobywanie żywności, w związku z czym generał Kurt Wahle z oddziałem wydzielonym został wysłany na zachód, do Serra Mecula, z zadaniem gromadzenia zaopatrzenia, podczas gdy siły główne maszerowały na Nanguar. Mieściły się tam duże portugalskie składy. Niemcy

${ }^{41}$ P. Brudek, Afryka..., s. 178. 
dotarli tam 2 grudnia, zajmując miejscowość siłami straży przedniej dowodzonej przez kapitana Kempnera. Chorąży Salgado, dowódca garnizonu, liczącego pięciu białych podoficerów oraz 36 żołnierzy i 14 policjantów z miejscowego zaciągu, został wzięty do niewoli we śnie. Rozkaz podpalenia magazynów w przypadku nadejścia nieprzyjaciela nie został więc wykonany. Najcenniejszą zdobyczą Niemców okazała się żywność, wystarczająca na pełne zaaprowidowanie askarisów i tragarzy przez kilkanaście dni ${ }^{42}$. W literaturze portugalskiej można przy tym znaleźć informacje o tym, że przednie niemieckie patrole odziane były w portugalskie mundury, w tym mundur zdarty z trupa majora Pinto, niefortunnego dowódcy Negomano, co miało wprowadzić w błąd wartowników, a Niemcom pozwoliło na uzyskanie zaskoczenia ${ }^{43}$.

W Mecula, dokąd zmierzał Wahle, wydarzenia potoczyły się jednak inaczej. Portugalski garnizon został uprzedzony przez uciekinierów z Negonamo o nadciaganiu Niemców. Siły obrońców obsadzały tam samo Serra Mecula (dowódca - kapitan Francisco Pedro Curado) ${ }^{44}$ oraz Montes Macolos. Placówkę w Montes Oizulos obsadzał posterunek złożony z plutonu piechoty. Niemcy ciągnęli wówczas na zachód, wzdłuż rzeki Jurenge. Czołówki niemieckie podeszły pod Serra Mecula 3 grudnia. Wywiązała się wówczas krótka wymiana ognia, w następstwie której straż przednia wycofała się, by czekać na nadejście sił głównych. Do pozycji portugalskich dotarło w tym czasie wsparcie - pododdział złożony z około 90 lokalnych żołnierzy, prawdopodobnie z nieregularnych formacji policyjnych, skierowany tam przez cywilnego komisarza rządu, Guerra Lagre, który zdawał się mieć lepsze rozeznanie w sytuacji niż pułkownik Sousa Rosa na swoim odległym stanowisku dowodzenia. Kapitan Curado był świadomy, że w pierwszym

42 J. Cann, op. cit., s. 137.

43 C. Gomes da, Portugal na Guerra: A Guerra nas Colónias, Lisboa 1925, s. 58-59.

44 Doświadczony, 44-letni oficer kolonialny. Pełnił służbę na Wyspie św. Tomasza i w Angoli, a następnie w czasie ekspedycji kolonialnych w Mozambiku. Wykazał się niepospolitą odwagą w czasie rebelii na Timorze Wschodnim w 1912 r., broniąc fortów Riac oraz Leu-Laco. W 1916 r. został przeniesiony do Mozambiku. Zyskał przydomek „Strażnika Rovumy” (port. Condestável do Rovuma). Z armii odszedł w stopniu podpułkownika po 40 latach służby, z czego 24 spędził w koloniach. 
starciu odparł jedynie czołowe ubezpieczenie i rozpoznanie nieprzyjaciela, a więc przygotowywał się na znacznie silniejszy atak.

Zanim jednak do tego doszło, siły niemieckie, do których ponownie dołączyły patrole przeszukujące teren w poszukiwaniu żywności, osiagnęły stan ośmiu kompanii z 10 karabinami maszynowymi. Oznaczało to, że przeciwko około 250 Portugalczykom ciągnęło około 1,8 tys. kombatantów pod sztandarem niemieckim. Do starcia doszło 6 grudnia, a działaniami atakujących dowodził generał Wahle, wspierany przez Heinricha von Schnee (gubernatora Niemieckiej Afryki Wschodniej), który miał osobiście uczestniczyć w zmaganiach. Niemcy, dążąc do ograniczenia strat, wybrali taktykę infiltracyjną (przenikania przez pozycje przeciwnika) w miejsce frontalnego ataku, co spowodowało, że działania trwały do 8 grudnia. Dowódca portugalski wykazał się przy tym dużymi umiejętnościami i znaczną odpornością psychiczną, nie dopuszczając do rozprężenia w podległych pododdziałach i wybuchu paniki. Było to znaczne osiągnięcie, biorąc pod uwagę obecność niedobitków spod Negomano i rozpowszechniane przez nich, wyolbrzymione i przesadzone, opowieści o liczebności i możliwościach bojowych przeciwnika. Ostatecznie przewaga liczebna, a także wyższość oddziałów niemieckich w zakresie doświadczenia i umiejętności bojowych, przeważyła szalę, zwłaszcza że obrońcom zaczęła wyczerpywać się amunicja. Curado rozkazał trwać na pozycjach do ostatniego naboju. Kiedy zamilkł ostatni karabin maszynowy obsadzony przez chorążego Viriato de Lacerda, doszło w kilku miejscach do walki wręcz, ale generalnie portugalscy żołnierze kolonialni zaczęli się poddawać, choć większość wybrała ucieczkę w dżunglę. W walce zginęło po stronie obrońców 67 żołnierzy miejscowych i europejski oficer, do niewoli dostało się ośmiu europejskich oficerów i podoficerów, 32 szeregowych. Wszystkie zdobyte przez Niemców karabiny maszynowe okazały się niezdatne do użytku, gdyż wymontowano z nich iglice. Straty niemieckie miały wynieść, według Portugalczyków, około 100 zabitych $^{45}$, ale wydaje się, że są one znacznie przeszacowane.

Następnie generał Wahle zarządził postój, podczas którego pochowano z wojskowymi honorami poległych obu stron, w tym chorążego Viriato de Lacerda. Niemiecki dowódca zaproponował białym Portugalczykom

45 C. Gomes da, op. cit., s. 59. 
zwolnienie z niewoli, pod warunkiem złożenia przez nich honorowej przysięgi, że do końca wojny nie będą walczyć przeciwko Niemcom. Rycerska propozycja została odrzucona, a Wahle, nie mając innego wyjścia, zwolnił jeńców, pozwalając przy tym kapitanowi Curado zachować białą broń. Dowódca obrony po powrocie do swoich został wysłany do Lourenço Marques, a później do Lizbony, ale wrócił do Mozambiku na własną prośbę w październiku 1918 roku.

Niemiecki pochód na zachód został zatrzymany przez obfite deszcze, ale Portugalczycy utracili do tego czasu placówki w Muembe (padła 19 grudnia 1917 roku) i Oizulos (27 grudnia). Z kolei Lettow-Vorbeck osiagną̧ 17 grudnia rejon Chirumla (Mtarica). 21 grudnia niemiecka grupa wydzielona w składzie kompanii wzmocnionej karabinami maszynowymi zajęła posterunek Meripo nad rzeką Lúrio. Nie był on broniony, gdyż Portugalczycy wycofali się dzień wcześniej, kiedy zwiadowcy wykryli niemiecką kolumnę i określili kierunek jej marszu. Następnie patrole przekroczyły Lúrio i zaatakowały placówkę w Muíte. Garnizon portugalski dowodzony przez kapitana Calixto Aníbala (dwa plutony piechoty) nie podjął walki i wycofał się w kierunku Mecubúri, osłaniany przez trzech białych podoficerów i dziesiątki żołnierzy. Ci ostatni jednak rychło rozproszyli się $e^{46}$.

Portugalczycy rozważali w tym czasie ewakuację Porto Amélia. Zapobiegło temu przybycie sił brytyjskich (pierwszy transportowiec wojskowy przybył 13 grudnia), które jednak działały niezależnie od portugalskiego dowództwa. Faktycznie siły kolonialne Lizbony znalazły się pod komendą brytyjską. Pułkownik Rosa został pod koniec grudnia odwołany - 3 stycznia 1918 roku zaczął pracę na statku Lourenço Marques i opuścił Mozambik. Gubernator Pereira Cabral, który stał za dymisją, postawił zadanie reorganizacji obrony kapitanowi Anibalowi Bessie dowodzącemu placówkami w Itoculo oraz Imala. Otrzymał on wzmocnienie w postaci plutonu regularnej piechoty, 240 żołnierzy formacji pomocniczych, używanych głównie do zadań wartowniczych oraz dwóch dziesiątek spieszonych marynarzy z krążownika Adamastor. Mimo że nie planowano pierwotnie

46 C. Bessa, O combate de Muite: aspectos relacionados com a participação portuguesa na guerra de 1914-1918 em Moçambique, Pelo académico correspondente... Separata dos Anais, II série, vol. 31, Lisboa 1986, s. 157-159. 
ich użycia w walce, Bessa wcielił wszystkich do formacji „liniowych”. Rozpoznanie portugalskie ustaliło, że Niemcy opuścili Muíte i rozbili obóz na północnym brzegu rzeki Lúrio. Bessa pomaszerował więc w kierunku opuszczonej przez przeciwnika placówki, obsadził ją 6 stycznia. Rozpoczęto przygotowywanie obrony. Wykonano linię okopów i stanowiska dla karabinów maszynowych, które wojska portugalskie nadal wykorzystywały anachronicznym „sposobem artyleryjskim” (jako wydzielone baterie, a nie w ugrupowaniu piechoty). Karabiny maszynowe zostały rozmieszczone na dominującym nad transzejami wzgórzu.

7 stycznia 1918 roku portugalski pluton, dowodzony przez chorążego Almadę Negreirosa, usiłował okopać się w rejonie pobliskich źródeł, by zapewnić garnizonowi dostęp do świeżej wody. W trakcie prac żołnierze, w większości z formacji pomocniczej, zostali zaatakowani przez siły niemieckie i po utracie dowódcy w panice uciekli. Był to początek ataku na Muíte. Atakowani z trzech stron żołnierze Bessy nie podjęli walki i zbiegli w busz. Pechowy dowódca został odcięty z pięcioma Europejczykami i czterema żołnierzami tubylczymi. Trzech białych (w tym Bessa zginęło) i dwóch askarisów zginęło. Łączne straty obrońców wyniosły 24 zabitych. Do niewoli dostał się europejski podoficer ${ }^{47}$.

Brytyjczycy, rozwijając siły opierając się na Porto Amélia, szybko zorientowali się, że występujące tam ograniczenia infrastrukturalne będące udziałem Portugalczyków dotyczą również ich. Ostatecznie oddziały zakwaterowano w doraźnie zorganizowanym obozie znajdującym się kilka kilometrów w głębi lądu. Do kwietnia Brytyjczycy rozwinęli się w kierunku zachodnim, dążąc do stworzenia pozycji uniemożliwiającej Niemcom odwrót na wschód. Działania te toczyły się już jednak przy znikomym udziale Portugalczyków. Do działań wprowadzano jedynie, w składzie sił Wspólnoty Brytyjskiej, pojedyncze pododdziały. Wynikało to między innymi z tego, że w kolonii kończyły się pieniądze. Żołnierze afrykańscy, nieopłacani, a dodatkowo borykający się z problemami aprowizacyjnymi i zdemoralizowani fatalnym poziomem opieki nad rannymi zaczęli masowo dezerterować. Sytuacja była tak zła, że pierwsze pododdziały udało się

47 Ibidem, s. 160. 
zreorganizować i doprowadzić do stanu umożliwiającego wymarsz w pole dopiero po czterech miesiącach i to z pomocą brytyjską.

Portugalczycy ponownie znaleźli się $\mathrm{w}$ walce na początku lipca 1918 roku. Von Lettow, który przemieścił się już z rejonów granicznych do centralnej części Mozambiku i operował w rejonie rzeki Licungo, ponownie został otoczony przez nieprzyjaciela. Niemiecka grupa wydzielona w sile trzech kompanii piechoty, poszukując słabego miejsca w ugrupowaniu brytyjskim zaciskającym się wokół własnych sił, uderzyła na stanowiska obsadzane przez dwie tubylcze kompanie portugalskie. Atakujący uderzyli na bagnety, zajmując, w ciągu trwającego dwie godziny boju, stanowiące rejon tyłowy przeciwnika zabudowania fermy cukrowniczej. Zginęło dwóch żołnierzy europejskich i około 100 miejscowych, do niewoli poszło 88 białych (w tym ośmiu oficerów i 10 pielęgniarek zajmujących się rannymi w taborze sanitarnym) oraz 200 żołnierzy z lokalnego zaciaggu. Zdobycz niemiecka obejmowała dwie armaty górskie kalibru 70 mm z 80 sztukami amunicji, dwa karabiny maszynowe, 280 karabinów i 100 tys. amunicji, a także znaczne zapasy środków medycznych (w tym chininy) ${ }^{48}$.

Następnego dnia dwie kompanie niemieckie zaatakowały pobliską stację (między portem Quelimana a Nhamacurra zbudowano połączenie kolejowe), gdzie spodziewano się zdobyć zaopatrzenie, zwłaszcza żywność. Zabudowania bronione były przez trzy kolonialne kompanie brytyjskie i trzy portugalskie. Co interesujące, mimo przewagi liczebnej Brytyjczycy i Portugalczycy poprzestali na pasywnej obronie. Dało to taki rezultat, że zdołali utrzymać pozycje, zaś po całodziennej wymianie ognia przeciwnik wycofał się, pozostawiając jednak ubezpieczenia obserwujące posunięcia obrońców. Okazało się, że w nocy Niemcy podciągnęli artylerię (zdobyczne portugalskie armaty górskie) i ostrzelali stację, zużywając 150 sztuk amunicji. Następnie do ataku ruszyła piechota wsparta karabinami maszynowymi. Obrona załamała się, żołnierze zaczęli w panice uciekać w kierunku miejscowości Nhamacurra, co jednak wymagało przeprawienia się przez rzekę. Utonął w niej ranny brytyjski dowódca major Gore-Browne. Poległo jeszcze czterech brytyjskich oficerów i około 200 żołnierzy. Do niewoli

48 M. Costa, É o inimigo que fala: Subsidios inéditos para o estudo da Campanha da áfrica Oriental. 1914-1918, Lourenço Marques 1932, s. 60-62. 
dostało się pięciu Brytyjczyków, 441 askarisów z pododdziałów brytyjskich i 117 żołnierzy portugalskich. Spośród wziętych do niewoli von Lettow zatrzymał dwóch lekarzy i czterech brytyjskich sierżantów, zaś resztę jeńców zwolniono 4 lipca.

W trakcie obu starć (1-3 lipca) Niemcy stracili czterech żołnierzy europejskich i 36 miejscowych ${ }^{49}$. Łup był również bardzo cenny: pięć ciężkich i dwa lekkie karabiny maszynowe, 444 karabiny, 227 tys. sztuk amunicji, 200 ton mąki kukurydzianej, 7 tys. litrów alkoholu, tysiąc racji żywnościowych dla Europejczyków i 175 tys. racji dla żołnierzy lokalnych, medykamenty, sprzęt kwatermistrzowski. Ponadto zdołano jeszcze przechwycić mały brytyjski parowiec rzeczny, którego szyper nie był świadomy rozgrywających się wydarzeń ${ }^{50}$. Na jego pokładzie znajdowało się 80 tys. sztuk amunicji do angielskich karabinów i znaczny zapas środków medycznych (przede wszystkim chininy) ${ }^{51}$. Był to wielki sukces niemiecki. Siły alianckie zostały w praktyce zamknięte w porcie Quelimane, który został już wcześniej umocniony. Obawa przed atakiem niemieckim była jednak tak duża, że na krążownik Adamastor zaokrętowano przebywające w mieście osoby cywilne. Niemcy w tym czasie, ogołociwszy tereny, na których operowali z zapasów żywności, skierowali się na północ, ku Tanganice. 7 lipca zajęli i spalili opuszczony posterunek portugalski w Iringa oraz zniszczyli na długim odcinku linię telefoniczną między Quelimane a Bajone. 23 lipca została zniszczona, obsadzona przez brytyjsko-portugalską załogę, placówka w Namirrue, gdzie rozproszono około 150 żołnierzy lokalnych dowodzonych przez białych oficerów. Niemcy zdobyli dwa lekkie karabiny maszynowe, 90 karabinów, 10 tys. sztuk amunicji i 15 koni ${ }^{52}$.

Dotychczasowy przebieg kampanii w Mozambiku był wyjątkowo niekorzystny dla Portugalii. Mimo wyekspediowania do kolonii czterech zgrupowań nie odniesiono żadnego sukcesu, straty były zaś bardzo poważne. Niepowodzenia w sferze wojskowej przełożyły się na niekorzystny rozwój wydarzeń w płaszczyźnie politycznej. Portugalia w istocie utraciła zdolność

P. Brudek, Afryka..., s. 223.

50 Ibidem, s. 215.

51 M. Costa, op. cit., s. 64.

52 P. Brudek, Afryka..., s. 216. 
do obrony Mozambiku, a co za tym idzie, jej suwerenność nad tym obszarem zaczęła się rozmywać. Pierwszym tego przejawem była utrata przez wojska kolonialne samodzielności operacyjnej. Operując na własnym terenie, zostały one sprowadzone do roli pomocniczej formacji brytyjskiej. Stosunki między sojusznikami układały się przy tym niekorzystnie. Brytyjscy oficerowie nie ukrywali pogardy dla Portugalczyków, których uważali za bufonów i tchórzy, niezasługujących na zaufanie na polu walki i niedbających - dodatkowo - o higienę. Do ograniczania do niezbędnego minimum kontaktów przyczyniła się również znaczna liczba przypadków syfilisu wśród białych portugalskich kombatantów. Relacje między Europejczykami przekładały się, w sposób oczywisty i bezpośredni, na miejscowych kombatantów.

Portugalczycy rozpaczliwie potrzebowali w Mozambiku żołnierzy, ale kraj zbliżył się do kresu swoich zdolności mobilizacyjnych, zaś turbulencje polityczne nie sprzyjały podejmowaniu nadzwyczajnych wysiłków. W 1918 roku udało się w metropolii zebrać batalion piechoty morskiej (z rezerw kadrowych marynarki) i wysłać go do Afryki na pokładzie krążownika São Gabriel. Żołnierze ci dotarli jednak do Afryki przed kapitulacją von Lettowa 25 listopada 1918 roku $^{53}$.

W czasie działań w Mozambiku Portugalczycy wystawili niemal 20 tys. żołnierzy z metropolii i ponad 10 tys. kombatantów z miejscowego zaciaggu. Straty w szeregach (jak można mniemać szacunkowe) były bardzo wysokie, wyniosły 4,8 tys. zabitych, 1584 rannych (w tym 1283 trwale okaleczonych), 678 wziętych do niewoli, 5467 zaginionych (zabici i dezerterzy) ${ }^{54}$. Straty miejscowej ludności cywilnej, głównie pośrednie, spowodowane rabowaniem żywności, nie podlegały dokładnym analizom, a jedynie pobieżnym szacunkom, padają cyfry między 15 a 40 tys.

53 Força Militar Colonial de Moçambique, http://www.momentosdehistoria.com/ MH_05_02_Exercito.htm, dostęp: 03.10.2018.

54 F. Rita, op. cit. 
Tabela 1. Portugalski wysiłek mobilizacyjny w Mozambiku 1914-1918

\begin{tabular}{|c|c|c|c|}
\hline Rok & Zgrupowanie & $\begin{array}{l}\text { Kombatanci } \\
\text { z metropolii }\end{array}$ & $\begin{array}{c}\text { Kombatanci } \\
\text { z zaciagu } \\
\text { miejscowego }\end{array}$ \\
\hline 1914 & 1 $^{\text {a }}$ Força Expedicionária & 1655 & \\
\hline 1915 & 2a Força Expedicionária & 1558 & \\
\hline 1916 & $3^{\mathrm{a}}$ Força Expedicionária & 4836 & \\
\hline 1917 & $4^{\mathrm{a}}$ Força Expedicionária & 5267 & \\
\hline 1917 & 4a Força Expedicionária (II rzut) & 4509 & \\
\hline 1918 & $\begin{array}{l}\text { Batalhão Marinha } \\
\text { (batalion piechoty morskiej) }\end{array}$ & 764 & \\
\hline $\begin{array}{c}1914- \\
1918\end{array}$ & $\begin{array}{l}\text { Oficerowie i podoficerowie } \\
\text { w pododdziałach z lokalnego } \\
\text { zaciaggu }\end{array}$ & 985 & \\
\hline \multicolumn{2}{|l|}{ RAZEM } & 19574 & 10278 \\
\hline \multicolumn{2}{|c|}{ ŁĄCZNIE } & \multicolumn{2}{|c|}{29852} \\
\hline
\end{tabular}

Źródło: Força Militar Colonial de Moçambique ${ }^{55}$.

Dla biednej Portugalii, w której stopa analfabetyzmu w niektórych regionach przekraczała $80 \%$, był to gigantyczny wysiłek. Skutkowało to kiepskim stanem uzbrojenia, wyekwipowania i zaopatrzenia oraz bardzo niskim poziomem wyszkolenia. Na to nałożyły się duża aktywność polityczna podoficerów i żołnierzy niesprzyjająca utrzymaniu dyscypliny, awanse wynikające z lojalności wobec reżimu republikańskiego, a także zwyczajne złodziejstwo. Źle wyszkoleni i uzbrojeni, fatalnie dowodzeni, pozbawieni często elementarnej opieki medycznej, ale i nawyków sanitarnych żołnierze metropolitalni przekazywali i zaszczepiali możliwie najgorsze wzorce rekrutom z metropolii. W rezultacie każdy kontakt bojowy z siłami niemieckimi, złożonymi w zasadniczej masie $\mathrm{z}$ afrykańskich askarisów ${ }^{56}$, kończył się porażką

55 http://www.momentosdehistoria.com/MH_05_02_Exercito.htm, dostęp: 05.03.2018.

$56 \mathrm{Z}$ arabskiego „żołnierz”. W ogólnym rozumieniu żołnierz (ewentualnie policjant) z lokalnego zaciągu, pełniący służbę w kolonialnych oddziałach organizowanych przez państwa europejskie. 
lub klęską. Można odnieść wrażenie, że w dobie Wielkiej Wojny Luzytanie nie dysponowali już żadnymi ze zdolności i umiejętności, które wcześniej umożliwiły im zbudowanie globalnego imperium handlowego, sięgającego od ujścia Tagu po Japonię.

Portugalia przystąpiła do Wielkiej Wojny z zamiarem znaczącego poprawienia swojej pozycji międzynarodowej oraz wzmocnienia tytułu do posiadania kolonii. Niepowodzenia wojskowe, zarówno na europejskim froncie zachodnim, jak i w Afryce, przekreśliły ten zamysł. Potwierdzaja to decyzje dotyczące Portugalii, podjęte na konferencjach w Wersalu i Spa. Stojący na czele delegacji luzytańskiej Afonso Augusto da Costa uzyskał jedynie uznanie suwerenności nad niewielkim terytorium na pograniczu między Mozambikiem a niemiecką Tanganiką (tak zwany trójkąt Kionga o powierzchni tysiąca $\mathrm{km}^{2}$ ) oraz potwierdzenie integralności kolonii, co w istocie nie oznaczało zbyt wiele ${ }^{57}$. Da Costa domagał się, co prawda, znacznych rekompensat finansowych $(20$ mld marek w złocie płatnych natychmiast $)^{58}$, części niemieckiej floty oraz powiernictwa nad terenami pozostającymi uprzednio pod administracją niemiecką (powoływał się na przykład Belgii, która otrzymała Rwandę i Burundi), a także zwrotu miasta Olivenza w hiszpańskiej prowincji Badajoz (zajętego przez Hiszpanów jeszcze w 1801 roku), ale roszczenia te zostały zignorowane. Charakterystyczna była przy tym postawa brytyjskiego ministra kolonii Alfreda Milnera, który zapytał da Costę, czy „Portugalia domaga się owych terenów, aby ponownie odkryć, dlaczego tak wielu tubylców w Mozambiku współpracowało z wojskami niemieckimi” ${ }^{59}$. Wszystkie te postulaty zostały odrzucone,

57 H. Strachan, The First World War in Africa, Oxford 2004, s. 161.

58 Portugalia żądała początkowo 8\% całości reparacji, jakie miały zapłacić Niemcy, następnie ograniczyła je do 2,5\%, ale na konferencji w Spa, która odbyła się w lipcu 1920 r., przyznano jej zaledwie 0,75\% (dla porównania - państwa Europy Środkowej i Wschodniej otrzymały łącznie 6,5\%, a sposób podziału miały wynegocjować między soba). Przyznano jej również prawo do zajętego w 1916 r. niemieckiego tonażu. Według kursu z 1920 r. Lizbonie przysługiwała kwota 50 mln funtów szterlingów. Sprawa reparacji ciągnęła się do lat trzydziestych, kiedy zamknęli ją premier António de Oliveira Salazar i kanclerz Adolf Hitler.

59 F.R. de Meneses, Post-war Settlement (Portugal), https://encyclopedia.19141918-online.net/article/post-war_settlement_portugal, dostęp: 19.03.2018. Milner 
ale dla Portugalii w przestrzeni międzynarodowej najbardziej upokarzające było to, że miejsce niestałego członka Rady Ligi Narodów, do którego aspirowała, zostało przyznane neutralnej w czasie Wielkiej Wojny Hiszpanii. Oznaczało to, że jeden z najważniejszych celów podjęcia walki, którym według republikanów było odzyskanie pozycji międzynarodowej, nie został osiągnięty. Mimo to Costa, szantażując parlament zagrożeniem kolonii ze strony Unii Południowoafrykańskiej, doprowadził do ratyfikacji traktatu wersalskiego przez Kortezy, ogłaszając przy tym, że „fakt odzyskania Kiongi jest wystarczający, by usprawiedliwić naszą interwencję w wojnie, gdzie portugalskie cnoty zostały tak wymownie wykazane" 60 . W narrację tę wpisywało się wzniesienie w Lourenço Marques (obecnie Moputo) pomnika zwycięstwa ${ }^{61}$. Tymczasem próba osiągnięcia przez Portugalię wymiernych korzyści politycznych poprzez użycie czynnika militarnego zakończyła się całkowitym fiaskiem ${ }^{62}$.

miał na myśli tubylcze rozruchy przeciwko Portugalczykom i zgłaszanie się do Niemców wodzów plemion z północy Mozambiku, którzy proponowali przyłączenie się do nich.

60 Ibidem..

61 WWI monument in Maputo, http://war-memorial.net/WWI-monument-in-Maputo-1.371, dostęp: 20.05.2019.

62 W szczególny sposób potwierdzają to zamiary von Lettowa z ostatniej fazy kampanii, by z brytyjskiej Rodezji pomaszerować do belgijskiego Konga, a następnie do portugalskiej Angoli, por. P. Brudek, Niemieckie wojska..., s. 234. 